\title{
THE ROLE OF SOCIAL CAPITAL AND TRUST IN CONTRACTING
}

\author{
Katarzyna Bentkowska, $\mathrm{PhD}^{1}$ \\ Collegium of Business Administration, Warsaw School of Economics
}

\begin{abstract}
The aim of the study is to analyse how the social capital in Poland affects contracting. It's role is significant as the contracts concluded on the market are incomplete, i.e. they do not regulate all the issues explicitly. The effects of contractual incompleteness can be mitigated by the high level of trust and well-developed social capital. However, the research results show that the level of trust in Poland has been low for years and that social capital remains underdeveloped. It prevents the social capital to fulfil its role as a factor supporting the conclusion of contracts properly. This results in a real loss for enterprises, as part of the transactions is not conducted.
\end{abstract}

Keywords: informal institutions, social capital, incomplete contracts

JEL codes: A13, L14, O17

\section{INTRODUCTION}

The activities of enterprises can be perceived in accordance with the institutional economics approach as continuous contracting. Of course, the enterprise itself is a bundle of contracts (Alchian and Demsetz, 1972). However, in order to exist and develop, it has to conclude contracts with partners on the market. The more contracts there are, the greater the scale of its operation, the greater the potential for profits and the more dynamic the enterprise's development becomes. In practice, contracts are characterized by a feature important for the enterprises i.e. they are incomplete. This means that it is impossible to specify explicitly all the rights and obligations of the parties or to take into account all circumstances. As a result, entities may be afraid of signing contracts with unverified partners because they fear their unreliability and difficulties in enforcing the contract.
Informal institutions, including social capital, play a significant role in signing contracts and the way they are performed. Well-developed social capital can mitigate the effects of contractual incompleteness and the lack of trust between the partners. It is worth considering how the social capital in Poland affects contracting.

\section{THEORETICAL BACKGROUND}

Institutional economy focuses on the key role of institutions in analysing the entities' operations. According to North's approach, institutions that are a set of fundamental political, social and legal principles forming the structure of production, distribution and exchange, can be divided into formal institutions, informal institutions and enforcement mechanisms (North, 1994). Formal institutions consist of the constitution, all legal regulations, administrative and

${ }^{1}$ Corresponding author: Szkoła Główna Handlowa, Instytut Rynków i Konkurencji, al. Niepodległości 162, 02-554 Warsaw, Poland, kbent@sgh.waw.pl,+4822 5649237 
technical rules. Informal institutions are customs, traditions, culture, religion, certain codes of conduct, norms of behaviour and adopted conventions. Enforcement mechanisms include norms of behaviour, penalties, sanctions and taxes which are voluntary or imposed by governments. They are designed to detect deviations from the adopted rules and to correct them.

Institutions form a structure for all the activities of everyday life and thereby reduce uncertainty, which is their main goal (North, 1994). Formal and informal institutions are interrelated. Formal institutions are supplemented with informal institutions. They may also be modified or even arise due to the existence of certain informal institutions. The effectiveness of formal institutions is therefore dependent on their compatibility with informal institutions.

According to the institutional economics approach, the existence of an enterprise is the result of transaction cost (Coase, 1937). It depends on transaction cost which transactions will be included in the company and which will be conducted on the market. If the cost of arranging transactions inside the enterprise is lower than on the market, one should decide to set up a company. Otherwise, the transaction should be organized on the market. Moreover the company should be increased until the cost of organizing transactions inside the company is lower than organizing them on the market. So this relates to the internal development of the enterprise.

However, here we will focus on the transactions conducted on the market. The company is looking for suppliers there, from whom it purchases the necessary goods and services. It looks also for partners, to whom it sells the goods and services it produces. If an enterprise wants to grow quickly and increase its potential for profits, it has to conduct more and more transactions. When we deal with the exchange process, we always face the problem of the agreement between the parties, of establishing their rights and obligations. So we enter the world of contracts. Contracts are understood here as agreements specifying the terms of the transaction and the obligations of the parties.

Contracts play a significant role in coordinating economic activities and ensuring trade's safety. The growing interest in contracts is often justified by the fact that the personal relationship between the entities are becoming weaker. Moreover social norms guaranteeing satisfactory contracts' fulfilling are too weak. The exchange of goods and services in the global economy is far from traditional patterns. Besides today we are dealing with growing transaction cost and increasing complexity of contracts. As a result the solutions used in the contracts that have been appropriate even recently, now begin to fail.

Institutional economy draws attention to an important issue related to contracting i.e. contracts' incompleteness. In theory, there are complete (or full) contracts including all the variables that may affect the partners' relationship (Stankiewicz, 2012). In complete contracts the parties specify precisely their rights and obligations for all possible states of the contract's implementation in the future. It is therefore fully enforceable. A complete contract presupposes the legal consequences of every possible solution, foresees all eventual circumstances. However certain conditions must be met if the contract is to be full. The contracting parties must be rational, strive for maximization, have access to full information and have stable preferences.

In the real world there is no full information of course. Besides entities have to deal with information asymmetry, they are bounded rational, their behaviour is opportunistic, there is uncertainty and there are transaction costs. We can therefore treat the complete contract as a certain pattern. A pattern to which the parties may be heading. However, this is not necessarily desirable to make the contracts complete because it would entail high transaction cost and become too time-consuming.

So in practice we deal with incomplete contacts (Hart, 1988; Royal Swedish Academy of Sciences, 2016). They contain some gaps, ambiguities, missing clauses. The contracts neglect many variants of future situations, because they are considered unlikely or they are not expected at all. The parties may sign an incomplete contract and then complete it and renegotiate if necessary during the implementation. They can use judicial or non-judicial proceedings. Besides, not all the gaps in the contracts are dangerous. Sometimes the law contains rules that fill such gaps. More- 
over the parties may also try to reduce unpredictability by making the duration of contracts shorter.

Undoubtedly, the legal order plays an important role in contracts' implementation. However, even the best formal institutions are not enough to regulate relations between entities (Lissowska, 2008). In some cases it is difficult to enforce contracts even in the court. The costs associated with such solution are often very high. In addition, we face the increasing complexity of economic relations and the attempts to specify all the complexities and nuances are connected with more and more problems. Furthermore the law is sometimes obsolete and also contains some gaps. Therefore, it is stressed that as the contracts are embedded in the institutional system of social contractual relations, their implementation is supported by the so-called private order. So we can say that there are some social norms, such as honesty, reliability, trust, will to keep promises, which constitute the informal institutions (Staniek, 2017).

Thus, we come to the key role of informal norms for contracting. Such informal norms provide better performance of incomplete contracts. Let's pay special attention to social capital being part of informal institutions. Social capital can be understood as a set of informal values and ethical standards common to the members of a specific group and enabling them to cooperate effectively (Fukuyama, 2003; Sierocińska, 2011; Sztompka, 2016).

Beyond doubt, the general incompleteness of contracts leads to entities' opportunistic behaviour. At the same time the lack of social acceptance of such behaviour, associated with a high level of trust and social capital may reduce such opportunistic behaviour. Well-developed social capital can mitigate the effects of contractual incompleteness and distrust between partners. If the society lacks the confidence that business is conducted honestly, that the partners can be trusted, that they care about their reputation, fulfil their obligations and act in good faith, it has little chance for dynamic development.

The research show there is a strong relationship between the level of social capital and the dynamics of economic growth. Nations with a high level of social capital are wealthier (Krajowy Rejestr Długów, 2015). Social capital decreases transaction cost and reduces the risk of running a business. With highly developed social capital entrepreneurs proceed reliably not only because of a threat someone may impose legal sanctions. They do it because they fear losing good reputation and being excluded from a group of trustworthy enterprises.

The article is to analyse how the social capital in Poland may affect concluding contracts by the enterprises.

\section{RESULTS AND DISCUSSION}

In the analysis there will be used data concerning the level of trust and assessment of social capital in Poland. The emerging evaluation of social capital in Poland is however unfavourable.

The results of the Social Cohesion Survey conducted by the GUS (Statistics Poland) show that the Poles trust primarily people in their immediate environment, i.e. the closest family (98\%) and friends (93\%). Unfortunately, strangers face much lower level of trust - only about $39 \%$ people trust them.

The image of the Poles as distrustful is also presented by the reports of the Center for Public Opinion Research (CBOS). Only $23 \%$ of respondents believe that most people can be trusted and $74 \%$ think that caution in needed while dealing with other people (Centrum Badania Opinii Społecznej, 2016). In business relations the Poles also follow the principle of limited trust. $35 \%$ of respondents believe that business trust generally pays off. However, up to $40 \%$ have of the opposite opinion.

The level of social trust in Poland has for years reached one of the lowest values in Europe. According to the European Social Survey 2014, Poland is at the end of the ranking in terms of general trust (ESSERIC, 2014). From the answers to three questions about trust in human contacts, assessing the readiness of the others to cheat and caring for their own interests only, one could get 30 points. Poland gained less than 13 points.

According to Skarżyńska, who studies the problem of low level of trust, it may result from several factors. One can mention the shock of transformation, turbulent history, social structure composed of isolated groups or authoritarian upbringing, which 
'carries the message that the world is ruled by force, people are divided into strong and weak, and you can only trust your relatives' (Podgórska, 2010).

Making comments on the low level of social capital in Poland and the associated low level of trust, Czapiński also points out that the Poles identify themselves with a small group of people, mainly the family, and trust only them. This results in the increase of transaction cost because 'in the relationships with strangers, one needs to apply a multitude of safeguards'. The effect is the diminishing creativity because people are less open and less inspired by each other. The stronger the bonds in such closed group, the worse become the relations of its members with potential clients or co-operators (Żakowski, 2010).

The lack of trust can also be seen in research directly related to business relationship. The report 'Social Capital and Trust in Polish Business 2015' shows that more than half of the entrepreneurs surveyed doubt the integrity of their contractors. They believe that 'most Polish entrepreneurs use a legal loophole in the contract to obtain additional benefits from the contract at the expense of the other party'. Only less than $9 \%$ definitely disagree with such opinion. At the same time, almost $60 \%$ admit that most entrepreneurs play fairly only if it's favourable for both sides, not only for the contractor. Of course, such approach affects the way of doing business. Entrepreneurs who do not trust their partners deal with them carefully and recognize that they should be constantly careful so as not to be deceived. Almost half of the entrepreneurs estimate that the lack of trust does not affect the resignation from conducting transactions. But a similar percentage $-47 \%$ - say that a part of the transaction is not conducted due to the lack of trust. As a result, their profits may be lower and their development becomes slower. Moreover as many as $27 \%$ of respondents declare that due to the lack of trust, they cooperate only with verified contractors and give up signing contracts with new partners. At the same time, entrepreneurs feel that their partners do not trust them. They admit that many transactions are not conducted because they are treated by the other entrepreneurs as strangers. $35 \%$ of respondents feel this way, while $58 \%$ do not perceive such problems. More than a half of entrepreneurs admit that one has to constantly gather evidence of his integrity - otherwise the partner may want to prove his negligence (Krajowy Rejestr Długów, Rzetelna Firma, 2015).

Koźmiński, describing the character of Polish entrepreneurs, draws attention to the cultural inability to establish alliances and loyal cooperation. This is referred to as the 'lonely wolf syndrome' (Koźmiński, 2004). Lack of trust itself may be the caused by the acceptance for opportunistic behaviour in the society. Growing competition on the market has increased the tendency among entrepreneurs to fight aggressively and pressure on using unfair practices in order to defeat the opponent (Strzyżewska, 2008). These are undoubtedly not the norms facilitating the conclusion of contracts. Trust in relatives does not help here, because the enterprise in order to develop has to build new relationship constantly and expand the group of its partners. But it is difficult to achieved it in the world of incomplete contracts with a low level of trust.

The report 'Social Diagnosis' draws attention to the fact that if high level of social capital is the essence of a society able to develop in an increasingly competitive market environment, then Poland with very low indicators of factors contributing to social capital doesn't have the best prospects. Meanwhile, the results of the analysis confirm a significant relationship between social capital and the wealth of Polish sub-regions. In 2014, the average level of social capital of the 66 sub-regions explained $37 \%$ of GDP differentiation (Czapiński and Panek, 2015).

The report 'Social Capital and Trust in Polish Business 2015' shows that the value of transactions that have not been conducted for fear of contractors' dishonesty can be estimated at PLN 145 billion to 215 billion, or at about $10 \%$ of GDP. The lack of actions increasing the trust in the companies resulted in the loss of the possibility to conclude contracts worth PLN 66.3 billion, or about 3\% of GDP. In total, one can assume losing even 13\% of GDP in 2014 only (Krajowy Rejestr Długów, Rzetelna Firma, 2015). This shows that all the attempts to raise social capital and the level of trust can be turned into real profits for enterprises. 
International research show that for poorer countries the human capital is a more important premise of development than the social capital. Poland still belongs to this group of countries. However, after exceeding a certain threshold of GDP, social capital becomes crucial for further development. This explains why Poland's economic growth has been relatively high so far despite the very low level of social capital. The moment Poland exceeds the threshold of GDP, above which further investment in human capital will cease to be enough to sustain economic development, supporting the social capital will become even more crucial (Czapiński and Panek, 2015).

\section{CONCLUSIONS}

The article analyses the role of social capital from a perspective that is not commonly used in the literature, i.e. it refers to institutional analysis and contract incompleteness. It is only a preliminary attempt to show the important role social capital plays in concluding incomplete contracts and should be addressed in more details in future research. But even this limited analysis indicates that the problem is vital for the enterprises in Poland and it is recommended to devote more attention to investigate it further.

The presented research results show that the level of trust in Poland has been low for years. Social capital has not developed sufficiently in order to fulfil its role as a factor supporting the conclusion of contracts. Entrepreneurs do not trust their partners, they are afraid of being deceived, they have a feeling that one needs to be protected as much as possible. It is difficult to be combined with the incompleteness of contracts that does not allow to specify all the conditions explicitly and to ensure full protection against the partners' opportunist behaviour. This results in a real loss for enterprises and the economy as a whole, as part of the transactions is not conducted. Undoubtedly, with a higher level of trust and better developed social capital, the consequences of contractual incompleteness would be less noticeable.

\section{REFERENCES}

1. Alchian, A., Demsetz, H. (1972). Production, Information cost and economic organization. American Economic Review, 62 (5), pp. 777-795.

2. Centrum Badania Opinii Społecznej - CBOS (2016). Zaufanie społeczne. Komunikat $\mathrm{z}$ badań 8/2016 [Social trust. Research report no 18/2016]. Warszawa.

3. Coase, R.H. (1937). The nature of the firm. Economica, 4, pp. 386-405.

4. Czapiński, J., Panek, T. (2015). Diagnoza Społeczna 2015 [Social Diagnosis 2015]. Rada Monitoringu Społecznego, Warszawa.

5. ESS-ERIC (2014). European Social Survey 2014. Retrieved from: http://www.europeansocialsurvey.org [Accessed 04.06.2018].

6. Fukuyama, F. (2003), Kapitał społeczny [Social capital]. In: Harrison, L.E., Huntington, S.P. (eds.) Kultura ma znaczenie [Culture matters]. Zysk i S-ka, Kraków, p. 169.

7. Hart, O.D. (1988). Incomplete Contracts and the Theory of the Firm. Journal of Law, Economics, \& Organization, 4 (1), pp. 119-139.

8. Krajowego Rejestru Długów (2015). Kapitał społeczny i zaufanie w polskim biznesie. Skrót raportu [Social capital and trust in Polish business. Summary of the report]. Wrocław.

9. Koźmiński, A.K. (2004). Czy polscy menedżerowie są przygotowani do konkurencji na rynkach Unii Europejskiej [Are Polish managers ready to compete in EU markets]. Master of Business Administration, 1, p. 16.

10. Lissowska, M. (2008). Instytucje gospodarki rynkowej w Polsce [Institutions for matket economy. The case of Poland]. C.H. Beck, Warszawa.

11. North, D.C. (1994). Institutions, institutional change and economic performance. Cambridge University Press, Cambridge.

12. Podgórska, J. (2009). Pęknięty autoportret [A broken self-portrait]. Polityka of 06.12.2009.

13. Royal Swedish Academy Of Sciences (2016). Oliver Hart and Bengt Holmström: contract theory. Scientific Background on the Sveriges Riksbank Prize in Economic Sciences in Memory of Alfred Nobel 2016, Stockholm.

14. Sierocińska, K. (2011). Kapitał społeczny. Definiowanie, pomiar i typy [Social capital. Definitions, measurment and types]. Studia Ekonomiczne. Polska Akademia Nauk, Instytut Nauk Ekonomicznych, 1 (68), pp. 69-86. 
Proceedings of the 2018 International Scientific Conference 'Economic Sciences for Agribusiness and Rural Economy' No 2, Warsaw, 7-8 June 2018, pp. 267-272

15. Staniek, Z. (2017). Ekonomia instytucjonalna. Dlaczego instytucje są ważne [Institutional economics. Why institutions matter]. Difin, Warszawa.

16. Stankiewicz, W. (2012). Ekonomika instytucjonalna. Zarys wykładu [Institutional economics. Lecture's draft]. Wydawnictwo Prywatnej Wyższej Szkoły Businessu, Administracji i Technik Komputerowych, Warszawa.

17. Strzyżewska, M. (2008). Polskie przedsiębiorstwa na rynkach Unii Europejskiej [Polish enterprises on EU markets]. In: Nowakowski M.K. (ed.) Eurobiznes [Eurobusiness]. Oficyna Wydawnicza SGH, Warszawa.

18. Sztompka, P. (2016). Kapitał społeczny. Teoria przestrzeni międzyludzkiej [Social capital. Theory of interpersonal space]. Znak. Kraków.

19. Żakowski, J. (2010). Polska smuta - rozmowa z prof. J. Czapińskim [Polish sadness - interview with prof. J. Czapiński)]. Polityka of 09.04.2009. 